\title{
The Effects Of Ownership Structure And Listed Status On Bank Risk In China
}

Maoyong Cheng, Xi'an Jiaotong University, P.R. China

Hong Zhao, Ph.D., Xi'an Jiaotong University, P.R. China

Junrui Zhang, Ph.D., Xi'an Jiaotong University, P.R. China

\begin{abstract}
This paper investigates the relationship of ownership structure, listed status and risk by using regression analysis based on the relevant data of China's commercial banks. Three main results emerge. First, compared to the state-owned banks, foreign-owned commercial banks exhibit better asset quality, lower credit risk and higher capital adequacy ratio; city commercial banks have lower credit risk and joint-stock commercial banks have lower credit risk and capital adequacy ratio. Second, listed status improves the asset quality and capital adequacy ratio. Finally, we also find that the listed status significantly moderates the relationship between ownership structure and risk. In conclusion, this study provides a theoretical reference for the reform of China's commercial banks.
\end{abstract}

Keywords: Commercial Bank; Ownership Structure; Listed Status; Risk

\section{INTRODUCTION}

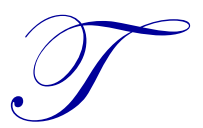

hough China's banking industry has implemented a series of banking system reforms over the last three decades, this enormous banking system is far from being a developed, efficient, and higher market degree. The higher non-performing loans ratio, lower capital adequacy ratio, lower profitability, and lower efficiency are the features of the Chinese banking industry. The development of China's banking industry has reached a critical juncture. The reforms' spearhead directly pointed to the ownership reform of China's banking industry, which was launched in 2003 and achieved a fundamental break in banking ownership structure. In January 2004, the State Council of the People's Republic of China decided that Bank of China and China Construction Bank be the first to implement the joint-stock reform, and proposed the overall objective, i.e., transforming the two banks to modern joint-stock commercial banks with enough capital, strict internal control, safe operation, higher efficiency, and possessing international competitiveness in three years. Based on the idea of reform, "Financial restructuring, Joint-stock reform, the inducting of strategic investors, and IPO", Bank of China, China Construction Bank, Industrial and Commercial Bank of China, Bank of Communications, and other commercial banks have introduced strategic investors and been successfully listed on the Stock Exchange. The listed banks have become the main body of China's banking industry. After three years' hard work, China's banking industry has made a significant achievement. According to "The Banker", Industrial and Commercial Bank of China, China Construction Bank and Bank of China ranked first, second and fourth concerning the world's banks' profitability in 2008.

Ownership structure fundamentally determines the corporate governance mechanisms and behavior choices, thus affects bank performance and risk. Previous research of ownership structure about China's banking industry has focused on the implication of ownership structure on bank performance and efficiency (Berger, Hasan and Zhou, 2009; Fu and Heffernan, 2009; Lin and Zhang, 2009). However, research about how the ownership structure affects risk in China's banking industry is blank. Any difference between state owned commercial banks and non state owned commercial banks? Therefore, we propose the first question: How does the ownership structure affect risk in China's banking industry? According to the idea of reform, domestic commercial banks have 
accelerated the listing pace ${ }^{1}$ since 2005. Bank of communications was listed at Hong Kong in June 2005 and at Shanghai in May 2007. Bank of China was listed at Hong Kong in June 2006, and then at Shanghai in July 2006. Industrial and Commercial Bank of China was listed at Hong Kong and Shanghai in October 2006. Then, Industrial Bank Co., Ltd., China CITIC Bank, Bank of Ningbo, Bank of Nanjing, Bank of Beijing and China Construction Bank were listed in succession. And in recent years, The Hongkong and Shanghai Banking Corporation Limited (China), Standard Chartered Bank (China) and Bank of East Asia (China) all have expressed they will accelerate the listing pace in mainland of China. Bank listing can change the ownership structure, but the implication of the former on bank risk is different from that of the latter. In theory, bank listing will impact risk from two aspects. On the one hand, bank listing exposes the bank to a more strict regulation, which will reduce bank risk. On the other hand, bank listing makes bank equity able to be raised at a lower cost, which induces banks to invest in the high-risk projects, and increases bank risk. However, there has been no empirical research on how the listed status impacts bank risk. The existing research all explores the implication of listed status on bank risk from the qualitative perspective. Therefore, we propose the second question: How does bank listing impact bank risk in the Chinese particular financial environment?

This paper investigates the two questions by using regression analysis based on the relevant data of China's 94 commercial banks during the period from 2001 to 2009. Three main results emerge. First, compared to the state-owned banks, the foreign-owned commercial banks exhibit a better asset quality, lower credit risk and higher capital adequacy ratio; the city commercial banks have lower credit risk than the state-owned banks; the joint-stock commercial banks have lower credit risk and capital adequacy ratio. Second, bank listing improves the asset quality and capital adequacy ratio, and reduces the credit risk to a certain extent, indicating the regulatory reinforcement effect of bank listing plays a leading role in China's listed banks. Third, the relationship between ownership structure and risk is different among the different listed status sample and the analysis of covariance shows that the listed status significantly moderates the relationship between ownership structure and risk. This paper extends the earlier work on bank ownership structure and bank risk in four directions. First, this is one of the first studies exploring the relationship between ownership structure and bank risk in China's banking industry. Second, we clearly propose the two effects of bank listing containing regulatory reinforcement effect and investment-pull effect, and explore how bank listing impacts bank risk in the Chinese particular financial environment. Third, we explore the implication of the interaction of ownership structure and listed status on bank risk by using the analysis of covariance. Finally, we compare different risk models using several measures, proxying for asset quality, credit risk and capital adequacy ratio.

The rest of this paper is laid out as follows. Section 2 presents an overview of China's banking system. Section 3 reviews some of the research literature on bank ownership structure, listed status, and risk. Section 4 shows our data, variables, hypotheses and models. Section 5 displays our empirical results, and Section 6 concludes.

\section{BACKGROUND}

China's banking industry has experienced an extraordinary reform process in the past three decades, and it has transformed from a mono-bank model to multi-bank model, from monopoly to competition and from long-term isolation to relatively open. This not only improves the banking system, but also strongly promotes China's economic development.

Banking reform was put on the agenda in 1978. The initial reform measures focused on modifying the structure of China's banking system and building a "two tiers" banking system. This resulted in four specialized state-owned banks devolved from the People's Bank of China, containing Bank of China, Agriculture Bank of China, China Construction Bank, and Industrial and Commercial Bank of China, the so-called "Big Four", which served mainly as policy-lending "conduits" for the government. In 1994, the government established three specialized "policy" banks, "Agricultural Development Bank of China, China Development Bank and the Export-Import Bank of China", which undertook the policy-related business of the "Big Four". By then the "Big Four" really became the commercial banks and China's banking industry achieved the separation between policy

\footnotetext{
${ }^{1}$ Before 2005, the Chinese banking industry had five listed banks: Shenzhen Development Bank Co. Ltd. (1991), Shanghai Pudong Development Bank (1999), China Minsheng Banking Corporation (2000), China Merchants Bank Co. Ltd. (2002), and Hua Xia Bank (2003).
} 
finance and commercial finance. In order to increase banking competitiveness, the joint-stock commercial banks were formed during 1986-2009, containing Bank of Communications, China Bohai Bank, China CITIC Bank, China Everbright Bank, China Merchants Bank, China Minsheng Banking Corp., Ltd., Evergrowing Bank, China Guangfa Bank, Hua Xia Bank, Industrial Bank Co. Ltd., Shanghai Pudong Development Bank, Shenzhen Development Bank, and China Zheshang Bank. This broke the monopoly format established by the "Big Four". With the implementation of the Commercial Bank Law in 1995, urban and rural credit cooperatives started to merge and then formed the city-level commercial banks. The first city commercial bank, Shenzhen City Commercial Bank, was built on June 22, 1995, and infused new blood into China's banking industry. City commercial banks are also joint-stock commercial banks, but limited to local business. Within the five-year period after the WTO accession (2001), customer types and geographic restrictions were gradually lifted. Since December 2006, there have been no discriminatory restrictions on foreign bank entry. This made many foreign banks enter into the Chinese financial market. By the end of 2008, 30 foreign-owned banks or joint venture banks have been registered in China; 75 banks from 25 countries and regions have 153 branches in China; 196 banks from 46 countries and regions have established 238 offices in China.

Although it suffered a series of reforms, the governance of China's banking industry has not been remodeled and improved. Many problems have not been really resolved, such as administrative intervention from government, irrational allocation of resources, the pattern of the old regime and institutional issues. From the banks' perspective, China's commercial banks once equaled the expansion of scale to development due to the lack of corporate governance, the bias of guiding ideology and philosophy, the weak risk management and internal control mechanism. Bank risk has been increasingly prominent, especially the high non-performing loans ratio. The non-performing loans in the "Big Four" reached 1.002 trillion Yuan in June 1997, accounting for $25.6 \%$ of all loans. The international media has accused China's banking industry as technically "bankrupt" at a period of time. The Economist magazine declared "China's four state-owned banks should be bankrupted three times" according to the contemporary non-performing loans and capital. China's banking industry has been described as "a time bomb" to China's economy. In order to resolve the bank risk, the Ministry of Finance issued 270 billion Yuan special treasury bonds to add to the capital for the "Big Four" in 1998. The state has also set up four asset management companies which removed 1.4 trillion Yuan non-performing loans from the "Big Four" in 1999. The extensive development model lead China's banking industry through a "Great development-Great bad-Great remove" road. Until 2003, the Standard \& Poor's also said that resolving non-performing loans in China's banking industry had been impossible.

The development of China's banking industry reached a critical juncture. The reforms' spearhead directly pointed to ownership reform. At the end of 2003, Bank of China and China Construction Bank became the ownership reform pilot banks and received 370 billion Yuan ( $\$ 45$ billion) exchange reserves injecting. Then the State Council proposed the reform idea, "Financial restructuring, Joint-stock reform, the introduction of strategic investors, and IPO", in January 2004. In order to promote and guide the two banks to improve their corporate governance and internal mechanisms, "Bank of China, China Construction Bank Corporate Governance Reform and Regulatory Guidelines" was promulgated in March 2004. Bank of China and China Construction Bank removed non-performing assets to Cinda and Orient asset management companies twice in May and June 2004. Exchange reserves injection, non-performing assets removal and regulatory guidelines not only improved its capital adequacy ratio and the quality of bank assets, but also promoted the two banks to improve the micro-mechanism. These created important conditions for the two banks' reform. Bank of China, established in Beijing in August 2004, achieved diversification in ownership structure and investors, which marked the banks' reform as having taken an important step. At the same time, the two banks were also constantly improving corporate governance. For example, Bank of China set up the modern corporate governance structure containing the company shareholders, board of directors, board of supervisors and senior management. Bank of China also appointed internationally renowned independent directors participating in decision-making and supervision, who played an effective checks and balances role on board decisions. To complement the subsidiary capital, improved asset-liability structure and capital adequacy ratio, the central bank and the China Banking Regulatory Commission promulgated the "Commercial Banks Issue Subordinated Debt Management Approach" on June 23, 2004. Then, Bank of China, China Construction Bank and China Minsheng Banking Corp., Ltd. successfully issued subordinated bonds in the inter-bank bond market, which set the stage for further reform. In addition, other state-owned commercial banks, such as Industrial and Commercial Bank of China, and the joint-stock commercial banks also stepped up internal reforms and carefully designed the overall program for the future reform. 
After state funding, financial restructuring, ownership reforming and banks listing, corporate governance has improved in China's banking industry; the operating basis, profitability, brand value and credibility all have significantly increased. In 2008, the net profit achieved 583.4 billion Yuan in China's banking industry, up 30.6\%, which is far higher than the global banking industry average. The total profit, profit growth and return on equity and other indicators all ranked as first in the world. The profit achieved 111.2 billion Yuan in the Industrial and Commercial Bank of China, up 35.2\%; 92.64 billion Yuan in China Construction Bank, up 34\%; 64.36 billion Yuan in Bank of China, up 14.42\%; and 28.393 billion Yuan in Bank of Communications Co. Ltd., up 40.05\%. Similarly, the capital adequacy ratio also significantly improved and reached more than $12 \%$ in the Bank of China, China Construction Bank and Industrial and Commercial Bank of China, respectively 13.4\%, 12.2\% and 13\%, much higher than the $8 \%$ regulatory requirements. In the joint-stock commercial banks, the capital adequacy ratio in China CITIC Bank and Industrial Bank Co., Ltd. significantly increased through IPO, especially China CITIC Bank reached $14.3 \%$. China Guangfa Bank reached up to $7 \%$ through financial restructuring and the introduction of strategic investors, close to the $8 \%$ regulatory requirements. The remaining also reached $8 \%$. The non-performing loans ratio kept the downward trend in the "Big Four". In addition, the non-performing loans ratio was $4.32 \%$ in Agriculture Bank of China, the remaining three banks were below 3\%, respectively $2.29 \%$ in Industrial and Commercial Bank of China, 2.21\% in China Construction Bank and 2.85\% in Bank of China. In the joint-stock commercial banks, in addition that non-performing loans ratio was 3.66\% in China Everbright Bank, $4.54 \%$ in Shenzhen Development Bank and 2.85\% in Industrial Bank Co., Ltd., the remaining banks were below 2\%.

\section{LITERATURES}

Since the pioneering work by Berle and Means (1932), the implication of ownership structure on firm performance and risk has been well studied in the literature (Jensen and Meckling, 1976; Fama, 1980; Shleifer and Vishny, 1997). Moving to the analysis of the banking industry, most literature has explored the relationship between ownership structure and performance (Micco, Panizza and Yanez, 2007; Lensink, Meeste and Naaborg, 2008; Berger et al., 2009; Lin and Zhang, 2009), whereas the relationship between ownership structure and risk has been investigated relatively less and most of that concentrated on United States and European banking industries. There has been little direct research on the Chinese banking industry concerning this issue.

The relevant research can be divided into three categories: the first category has explored the relationship between ownership concentration and risk; the second has tested the relationship between managerial stockholding and risk; the third has investigated the relationship between ownership nature and risk. The first category: Garcia-Marco and Robles-Fernandez (2008) found that the degree of ownership concentration in commercial banks had a negative impact on the level of risk-taking. Haw, Ho, Hu and $\mathrm{Wu}$ (2010) found that banks with concentrative ownership exhibited poorer performance, lower cost efficiency, greater return volatility, and higher insolvency risk. Shehzad, Haan and Scholtens (2010) found that concentrative ownership significantly reduced bank's non-performing loans ratio, and increased the capital adequacy ratio. Barry, Lepetit and Tarazi (2011) found that ownership structure was significant in explaining risk differences, and a higher equity stake of either individuals/families or banking institutions was associated with a decrease in asset risk and default risk.

The second category: Saunders, Strock and Travlos (1990) firstly tested the relationship between managerial stockholding and risk, and found a positive relationship between them. Moreover, they also found that banks controlled by shareholders took more risk than banks controlled by managers. Based on the research of Saunders et al. (1990), several studies found a significant effect of managerial stockholding on risk. Gorton and Rosen (1995) found that corporate control problems had importantly impact on bank risk, and managers often took more risky loans (commercial real estate construction and development) and fewer relatively safe loans (consumer). But Anderson and Fraser (2000) found that managerial stockholdings were positively related to total or firm-specific risk in the late 1980s. However, following legislation in 1989 and 1991 designed to reduce risk-taking, the relationship became negatively related in the early 1990s. Sullivan and Spong (2007) suggested that managerial stockholding could increase total risk, which was consistent with Saunders et al. (1990).

The third category is similar to our study: Iannota, Giacomo and Sironi (2007) found that public sector banks had poorer loan quality and higher insolvency risk than other types of banks while mutual banks had better loan quality and lower asset risk than both private and public sector banks. They also found that a higher ownership 
concentration was associated with better loan quality, lower asset risk and lower insolvency risk. Cornett, Guo, Khaksari and Tehranian (2010) found that state-owned banks held less core capital and had greater credit risk than privately-owned banks prior to 2001. In addition, from 1997 to 2000, the 4-year period after the beginning of the Asian financial crisis, the deterioration in core capital and credit quality of state-owned banks was significantly greater than that of privately-owned banks, especially for the countries that were hardest hit by the Asian crisis. However, state-owned banks narrowed the gap with privately-owned banks on cash flow returns, core capital and non-performing loans in the post-crisis period of 2001-2004. Angkinand and Wihlborg (2010) found that a large share of state ownership in the banking system was associated with greater risk-taking as measured by non-performing loans relative to capital, but foreign ownership was not associated with risk-taking as measured by non-performing loans relative to capital but with higher risk-taking as measured by Z-scores and the capital ratio alone. Forssbæck (2011) found that state-owned major shareholder had no significant impact on bank's non-performing loan ratio, and large foreign shareholders increased the bank's non-performing loan ratio.

The research on the Chinese banking industry: Jia (2009) showed that lending by state-owned banks was less prudent than lending by joint-equity banks, but had improved over time. Firth, Lin, Liu and Wong (2009) suggested that political connections played an important role in gaining access to bank finance, and loans of state-owned commercial banks mostly flowed to the state-owned enterprises (SOEs), and often became non-performing loans easily. Ferri (2009) stated that state-owned commercial banks burdened with non-performing loans from SOEs had higher non-performing loans ratio than city commercial banks. Lin and Zhang (2009) found that the "Big Four" state-owned commercial banks had the worst asset quality than other types of banks except the "policy" banks.

Another purpose of our paper is to examine whether bank listing affects risk. But to our knowledge there has been no attempt to explore the link between bank listing and risk. Only some research has used listed status as a controlling variable. Kwan (2004) found no difference in loan quality and earnings variability between listed BHCs and unlisted BHCs. Iannota et al. (2007) found listed banks had more loan loss provisions than unlisted banks; Nichols, Wahlen and Wieland (2009) found the same conclusion. Barry et al. (2011) found market forces seemed to align the risk-taking behavior of listed banks.

\section{DATA, VARIABLES, HYPOTHESES AND MODELS}

\subsection{Sample and Data}

We use income statements and balance sheets from 2001 to 2009 of China's commercial banks from the Fitch IBCA/Bureau van Dijk's Bank Scope database, the ownership information and the listed status from the China Banking Regulatory Commission, and the macroeconomic data from the Chinese Almanac of Finance. We start with the complete sample of banks (131 China's commercial banks) in Bank Scope. However, we end up with a smaller sample (94 China's commercial banks), as we apply some selection criteria. First, we delete the banks with less than three consecutive years of observations. Second, we exclude banks missing some variables. Finally, we apply a number of outlier rules to the main variables (roughly corresponding to the 1st and 99th percentiles of the distributions of the respective variables). Our final data set consists of 94 banks for a total of 351 bank-year observations for which we have both ownership and accounting data. For listed banks, we have a smaller data set, which consists of 93 bank-year observations from 15 banks. Table 1 reports the number of banks and the number of bank-year observations and Table 2 reports the descriptive statistics for all variables defined in section 4.2 and 4.4.

Table 1: Sample descriptive statistics

\begin{tabular}{lccccccc}
\hline Bank nature & O_Cs & O_Js & O_Fs & O_Gs & LISTs & UNLISTs & All \\
\hline Banks & 70 & 12 & 8 & 4 & 15 & 79 & 94 \\
OBs & 248 & 67 & 15 & 21 & 93 & 258 & 351 \\
\hline
\end{tabular}

Notes: O_Gs are the state-owner commercial banks. O_Cs are the city commercial banks. O_Js are the joint-stock commercial banks. O_Fs are the foreign commercial banks. LISTs are the listed banks. UNLISTs are the unlisted banks. 
Table 2: Variables descriptive statistics

\begin{tabular}{lccccc}
\hline Variables & N & Mean & Std. Dev. & Min & Max \\
\hline LLP & 351 & 0.0091 & 0.0065 & -0.0019 & 0.0329 \\
NPL & 351 & 0.0432 & 0.0480 & 0.0010 & 0.3105 \\
CAP & 351 & 0.0555 & 0.0306 & 0.0153 & 0.2764 \\
O_C & 351 & 0.7066 & 0.4560 & 0.0000 & 1.0000 \\
O_J & 351 & 0.1909 & 0.3936 & 0.0000 & 1.0000 \\
O_F & 351 & 0.0427 & 0.2025 & 0.0000 & 1.0000 \\
O_G & 351 & 0.0598 & 0.2375 & 0.0000 & 1.0000 \\
LIST & 351 & 0.2650 & 0.4419 & 0.0000 & 1.0000 \\
SIZE & 351 & 11.1435 & 1.8055 & 8.1971 & 15.9770 \\
L_A & 351 & 0.5496 & 0.0872 & 0.3374 & 0.8376 \\
D_A & 351 & 0.9050 & 0.0508 & 0.5036 & 0.9661 \\
LIQ & 351 & 0.1948 & 0.0633 & 0.0413 & 0.4475 \\
GDP & 351 & 0.1077 & 0.0162 & 0.0800 & 0.1300 \\
INF & 351 & 0.0307 & 0.0211 & -0.0080 & 0.0590 \\
\hline
\end{tabular}

Notes: LLP is the ratio of loan loss provisions to total assets. NPL is the ratio of non-performing loans to total loans. CAP is the ratio of equity to total assets. O_G is a dummy variable that equals 1 if the bank is a state-owner commercial bank, and zero otherwise. $\mathrm{O} \_\mathrm{C}$ is a dummy variable that equals 1 if the bank is a city commercial bank, and zero otherwise. O_J is a dummy variable that equals 1 if the bank is a joint-stock commercial bank, and zero otherwise. O_F is a dummy variable that equals 1 if the bank is a foreign commercial bank, and zero otherwise. LIST is a dummy variable that equals 1 if the bank is listed in a stock market at 2001-2009, and zero otherwise. SIZE is the log of total assets. L_A is the ratio of loans to total assets. D_A is the ratio of deposits to total assets. LIQ is the ratio of liquid assets to total assets. GDP is the annual percentage growth rate of GDP at market prices based on constant local currency. INF is measured by the consumer price index.

\subsection{Research Variables}

The dependent variable in this paper is bank risk. We consider different measures of bank risk commonly used in the literatures. We compute three measures of bank risk for each bank throughout the period under study on the basis of annual accounting data. First, we use "the ratio of loan loss provisions to total assets (LLP)" proposed by Iannota et al. (2007), which reflects the asset quality of a given bank. A higher value of LLP implies worse asset quality. Second, we use "the ratio of non-performing loans to total loans (NPL)" adopted by Shehzad et al. (2010), which measures the credit risk of a given bank. A higher value of NPL indicates higher credit risk. Finally, we also use "the capital adequacy ratio (CAP)" introduced by Shehzad et al. (2010), defined as the ratio ${ }^{2}$ of the equity to total assets. A higher value of CAP implies lower bank risk.

The independent variables in this paper contain ownership structure and listed status. Iannota et al. (2007) considered a firm's ownership structure to be defined by two main dimensions: the degree of ownership concentration and the nature of the owner. We use the nature of the owner to measure the ownership structure as the data about ownership concentration are difficult to obtain for those unlisted banks. According to the different ownership structures ${ }^{3}$, China's banking industry contains state-owned commercial banks (O_Gs), city commercial banks (O_Cs), joint-stock commercial banks (O_Js), and foreign commercial banks (O_Fs). O_Gs are controlled by the state, which contain Bank of China (BOC), the Agriculture Bank of China (ABC), China Construction Bank (CBC), and the Industrial and Commercial Bank of China (ICBC), the so-called "Big Four". O_Cs and O_Js are joint-stock commercial banks which have no state equity participation. They all have dispersed ownership, but still have some differences. The predecessors of O_Cs are those urban credit cooperatives established in the 1980s, and their ownership structure has a certain regionalism (mainly by the unit establishing the credit cooperatives, credit staff etc.), while O_Js are a national joint-stock institution. So, they are treated as different commercial banks in this paper. O_Fs refer to Chinese-foreign joint-equity banks and banks capitalized entirely by foreign funds,

\footnotetext{
${ }^{2}$ In 2004, China Banking Regulatory Commission promulgated and implemented the "Capital Adequacy Ratio of Commercial Bank Management Approach", which make the calculation of capital adequacy ratio be different from the previous measurement. In order to avoid the errors of measurement, we adopt the ratio of equity to total assets to measure bank's capital adequacy ratio.

${ }^{3}$ In the analysis, we did not introduce policy banks because policy banks have their special Policy mission compared to other banks.
} 
characterized by foreign control. Four static dummy variables are introduced: O_C for city commercial bank; O_J for joint-stock commercial banks; O_F for foreign commercial banks; O_G for state-owned commercial banks. These dummy variables equal one for the corresponding banks for all time periods. Bank listing implies differences in terms of market discipline and accesses to capital markets. We also use a dummy variable "LIST" to measure the bank listed status. The dummy variable equals one if the bank is listed in a stock market during 2001-2009, and zero otherwise.

\subsection{Theoretical Analysis and Research Hypotheses}

In this paper, we have two objectives: the first is to analyze whether commercial banks with different ownerships structure present significantly different risk, using O-Gs as a reference standard; the second is to examine whether bank risk varies systematically across different listed status.

Different ownership structures mean different corporate governance mechanisms and behavior choices, which affect bank risk. From the perspective of agency theory, first, Jia (2009) considered that O_Gs were less monitored by their owners and had worse corporate governance compared to other ownership structure banks, which makes the O_Gs likely to be less prudent. This will undoubtedly increase the risk of O_Gs. Second, in a financial crisis, O_Gs were more likely to be bailed out by the government (Jia, 2009). This makes managers in O_Gs exert less effort than other ownership structure banks or divert resources for personal benefits (Barry et al., 2011). Finally, Berger et al. (2009) and Lin and Zhang (2009) found that O_Gs were inefficient and had low profitability in the Chinese banking industry because of weak managerial incentives and misallocation of resources. Iannota et al. (2007) considered that the differences in the profitability and cost efficiency may in turn arise from different risk-taking behaviors. From the political view of state ownership, government intervention would lead O_Gs to consider more political factors rather than economic ones. First, loans of O_Gs mostly flowed to SOEs, and often became non-performing loans (Firth et al., 2009). Second, in order to meet the national macroeconomic regulation and control, O_Gs tend to assign resources to the industry supported by the state. But these resources do not recover frequently. This will undoubtedly increase the risk of O_Gs, i.e., O_Gs carry out policy-based lending that follows government directive rather than commercial considerations (Brandt and $\mathrm{Li}, 2003$; Cull and $\mathrm{Xu}, 2003$ ). In 2009, in order to stimulate the economy, the state focused on supporting the real estate industry and local financing platform, which made resources flow to these industries. But in the end of 2010, the state clearly proposed to compress the size of credit, especially that of the real estate industry, which undoubtedly increased the difficulty of regaining these resources in the real estate industry. Therefore, we propose Hypothesis 1.

Hypothesis 1: Compared to other ownership structure banks, O_Gs have the higher risk (worse asset quality, higher credit risk and lower capital adequacy ratio).

Bank listing implies differences in terms of market discipline and access to capital markets. For listed banks, market forces can influence risk-taking incentives. On the one hand, bank listing means that banks face stricter capital regulation (first pillar in Basel II Capital Accord) and banking supervision, which makes managers mitigate risk-taking behavior. We call this the regulatory reinforcement effect. On the other hand, listed banks have different objectives in terms of growth and risk-return strategies. Listed equity is more liquid than unlisted equity and thus can be raised at a lower cost. Therefore, listed banks have more opportunities to grow fast, which promote them more likely to take on more risk than unlisted banks. We call this the investment-pull effect. Therefore, we propose two opposing hypotheses 2 .

Hypothesis 2a: Listed banks have lower risk than unlisted banks (better asset quality, capital credit risk and lower higher adequacy ratio).

Hypothesis 2b: Listed banks have higher risk than unlisted banks (worse asset quality, higher credit risk and lower capital adequacy ratio). 


\subsection{Methods}

To examine whether bank risk varies systematically across different bank ownership structures and listed status, the following regression model is estimated:

$Y_{i t}=\alpha+\beta X_{i t}+\sum_{k=1}^{K} \gamma_{k} B V_{k i t}+\sum_{m=1}^{M} \varphi_{m} E V_{m i t}+\varepsilon_{\mathrm{it}}$

Where $Y_{i t}$ is the observed asset quality, credit risk and capital adequacy ratio for the ith bank at year $t$; $X_{i t}$ contains the ownership structure variable $\left(\mathrm{X}_{1}\right)$ and the listed status variables $\left(\mathrm{X}_{2}\right)$; $\mathrm{BV}$ (banks variables) and EV (macroeconomic variables) are the controlling variables, which are chosen based on the reference (Iannota et al., 2007; Shehzad et al., 2010; Barry et al., 2011). $\alpha, \beta, \gamma, \varphi$, the regression coefficients; and $\varepsilon$, the disturbance term.

Table 3 reports the all variables summary.

Table 3: The summary of variables

\begin{tabular}{lll}
\hline & Variables & \multicolumn{1}{c}{ Definition } \\
\hline Y & LLP & The ratio of loan loss provisions to total assets \\
& NPL & The ratio of non-performing loans to total loans \\
& CAP & The ratio of equity to total assets \\
A dummy variable that equals 1 if the bank is a city commercial bank, and zero otherwise \\
$\mathrm{X}_{1}$ & O_C & A dummy variable that equals 1 if the bank is a joint-stock commercial bank, and zero otherwise \\
& O_J & A dummy variable that equals 1 if the bank is a foreign commercial bank, and zero otherwise \\
& O_F & A dummy variable that equals 1 if the bank is a state-owner commercial bank, and zero otherwise \\
$\mathrm{X}_{2}$ & O_G & A dummy variable that equals 1 if the bank is listed in a stock market at 2001-2009, and zero \\
& SIZE & otherwise \\
BV & The log of total assets \\
& D_A & The ratio of loans to total assets \\
& LIQ & The ratio of deposits to total assets \\
& GDP & The ratio of liquid assets to total assets \\
EV & The national GDP growth rate \\
& INF & Consumer price index
\end{tabular}

\section{EMPIRICAL RESULTS ${ }^{4}$}

\subsection{Does Risk Vary According to Bank Ownership Structure and Listed Status?}

Table 4 reports the OLS regression results of Eq. (1) with bank risk and its components, asset quality (columns 1,2 and 3), credit risk (columns 4, 5 and 6) and capital adequacy ratio (columns 7,8 and 9) as dependent variables. For each of these measures we run three OLS regressions. The first columns $(1,4$ and 7$)$ do not take into account the listed status variables of the banks. The second columns $(2,5$ and 8$)$ do not take into account any difference in the ownership structures of the banks. In the other columns (3,6 and 9), the set of explanatory variables includes O_C, O_J, O_F and LIST. Here, the dummy variable for O_G is excluded so that the estimated coefficients of O_C, $\mathrm{O}_{-} \mathrm{J}$ and $\mathrm{O} \_\mathrm{F}$ measure the effect of each ownership structure on risk relative to O_Gs.

Columns 1, 2 and 3 report the results for regressions of asset quality. Again, the dummy variable for O_G is excluded. O_F in columns 1 and 3 are both statistically significant (respectively at the 1\% and $1 \%$ level) and have a negative coefficient, denoting that O_Fs have better asset quality compared to O_Gs. It is consistent with Hypothesis 1. But O_C and O_J in column 1 and 3 are not significant, indicating that O_Cs and O_Js have no significantly different asset quality compared to O_Gs. It is inconsistent with Hypothesis 1 . This is due to the reform of O_Gs which improves the corporate governance level of O_Gs, and then improves the asset quality. This makes no obvious difference between O_Gs and O_Cs, O_Js. The LIST dummy variable has a significantly (respectively at

\footnotetext{
${ }^{4}$ We first perform t-tests for risk of O_Cs vs O_Gs, O_Js vs O_Gs, O_Fs vs O_Gs, and listed vs unlisted banks. The results, not reported, confirm our regression finding.
} 
the $10 \%$ and $1 \%$ level) negative coefficient in both columns 2 and 3 . These findings indicate that listed banks have better asset quality than unlisted banks. It is consistent with Hypothesis 2a, i.e., the regulatory reinforcement effect of bank listing plays a leading role in China's listed banks. The SIZE (in columns 1, 2 and 3), L_A (in column 2), LIQ (in columns 2 and 3), and GDP (in columns 1, 2 and 3) all exhibit significantly negative coefficients; the D_A (in column 2) is significantly positive; and the INF (in columns 1, 2 and 3) is not significant.

Columns 4,5 and 6 report the results for regressions of credit risk. The dummy variable for O_G is excluded. O_C, O_J and O_F in columns 4 and 6 are all statistically significant (at least at the 5\% level) and have negative coefficients, denoting that O_Cs, O_Js and O_Fs have lower credit risk compared to O_Gs. It is consistent with Hypothesis 1. The LIST dummy variable has no significant coefficient in both columns 2 and 3, indicating there is no significant difference in the credit risk between listed banks and unlisted banks. This is inconsistent with Hypotheses $2 \mathrm{a}$ and $2 \mathrm{~b}$. But we found the listed banks have lower credit risk in column 6 in Table 5 when we exclude the O_Fs. This is because the O_Fs are unlisted banks and have lower credit risk compared to other ownership structure banks, and the presence of O_Fs has directly reduced the average credit risk in unlisted banks. This makes the difference not significant between listed banks and unlisted banks. We believe that bank listing can still reduce the credit risk to some extent. The L_A (in column 5), LIQ (in columns 4, 5 and 6), and INF (in columns 4, 5 and 6) all exhibit significantly negative coefficients; the SIZE (in column 5) is significantly positive; while the D_A and the GDP are not significant in the three columns.

Columns 7, 8 and 9 report the results for regressions of capital adequacy ratio. The dummy variable for O_G is excluded. O_F in columns 7 and 9 are both statistically significant (respectively at the $1 \%$ and $1 \%$ level) and have a positive coefficient, denoting that O_Fs have higher capital adequacy ratio compared to O_Gs. It is consistent with Hypothesis 1. In columns 7 and 9, O_C is not significant and O_J has a negative coefficient, indicating O_Gs have higher capital adequacy ratio compared to O_Js and have no differences compared to O_Cs. It is inconsistent with Hypotheses 1. This is due to two reasons: first, the more problem loans forced O_Gs to keep higher capital adequacy ratio due to the principle of prudence; second, the CBRC (China Banking Regulatory Commission) has the higher capital requirements (11.5\%) for the large state-owned commercial banks. The LIST dummy variable in column 9 has a significant (respectively at the 1\% level) positive coefficient. These findings indicate that listed banks have higher capital adequacy ratio than unlisted banks. It is consistent with Hypothesis 2a, i.e., the investment-pull effect of bank listing plays a leading role in China's listed banks. The L_A (in columns 7, 8 and 9) and INF (in column 8) exhibit significantly positive coefficients; the D_A (in columns 7, 8 and 9) and GDP (in columns 7, 8 and 9) have negative coefficients; while the SIZE and LIQ are not significant in three columns.

Table 4: Regressions of bank ownership structure, listed status and risk

\begin{tabular}{|c|c|c|c|c|c|c|c|c|c|}
\hline & \multicolumn{3}{|c|}{ LLP } & \multicolumn{3}{|c|}{ NPL } & \multicolumn{3}{|c|}{ CAP } \\
\hline & 1 & 2 & 3 & 4 & 5 & 6 & 7 & 8 & 9 \\
\hline \multirow{2}{*}{ O_C } & -0.0012 & & -0.0020 & $-0.0827^{* *}$ & & $-0.0908^{* *}$ & 0.0014 & & 0.0044 \\
\hline & $(-0.5200)$ & & $(-0.9900)$ & $(-2.4000)$ & & $(-2.4900)$ & $(0.2900)$ & & $(0.9000)$ \\
\hline \multirow{2}{*}{ O_J } & -0.0016 & & -0.0005 & $-0.0753^{* * * *}$ & & $-0.0635^{* * * *}$ & $-0.0145^{* * *}$ & & $-0.0189^{* * *}$ \\
\hline & $(-1.2700)$ & & $(-0.3200)$ & $(-3.2300)$ & & $(-2.9800)$ & $(-3.2900)$ & & $(-3.9900)$ \\
\hline \multirow{2}{*}{ O_F } & $-0.0060^{* * * *}$ & & $-0.0072^{* * * *}$ & $-0.0739^{* *}$ & & $-0.0865^{* *}$ & $0.0338^{* * * *}$ & & $0.0384^{* * * *}$ \\
\hline & $(-2.8900)$ & & $(-4.0200)$ & $(-2.3100)$ & & $(-2.6200)$ & $(5.8700)$ & & $(5.6800)$ \\
\hline \multirow{2}{*}{ LIST } & & $-0.0021^{*}$ & $-0.0030^{* * * *}$ & & -0.0306 & -0.0324 & & -0.0027 & $0.0120^{* * * *}$ \\
\hline & & $(-1.9600)$ & $(-3.3600)$ & & $(-1.6600)$ & $(-1.6300)$ & & $(-1.1600)$ & $(3.0100)$ \\
\hline \multirow{2}{*}{ SIZE } & $-0.0009^{* *}$ & $-0.0005^{* *}$ & $-0.0006^{*}$ & -0.0041 & $0.0088^{* *}$ & -0.0015 & -0.0002 & -0.0014 & -0.0011 \\
\hline & $(-2.4100)$ & $(-2.1700)$ & $(-1.7700)$ & $(-1.1200)$ & $(2.3700)$ & $(-0.3600)$ & $(-0.1200)$ & $(-1.5500)$ & $(-0.9700)$ \\
\hline \multirow{2}{*}{ L_A } & -0.0011 & $-0.0033^{* * * *}$ & -0.0020 & -0.0589 & $-0.0375^{*}$ & -0.0691 & $0.0643^{\text {*** }}$ & $0.0623^{* * * *}$ & $0.0681^{* * * *}$ \\
\hline & $(-0.6100)$ & $(-3.1300)$ & $(-1.4900)$ & $(-1.6200)$ & $(-1.6700)$ & $(-1.5000)$ & $(8.8600)$ & $(5.3300)$ & $(9.2200)$ \\
\hline \multirow{2}{*}{ D_A } & $0.0088^{*}$ & $0.0155^{* *}$ & 0.0058 & 0.1057 & 0.0525 & 0.0734 & $-0.2869^{* * * *}$ & $-0.3613^{* * * *}$ & $-0.2750^{* * * *}$ \\
\hline & $(1.7100)$ & $(2.4600)$ & $(1.2200)$ & $(1.0000)$ & $(0.6800)$ & $(0.7500)$ & $(-4.7000)$ & $(-7.2100)$ & $(-4.2400)$ \\
\hline \multirow{2}{*}{ LIQ } & -0.0139 & $-0.0174^{* *}$ & $-0.0140^{*}$ & $-0.0990^{*}$ & $-0.1191^{*}$ & $-0.1002^{*}$ & 0.0102 & 0.0226 & 0.0106 \\
\hline & $(-1.6600)$ & $(-2.2000)$ & $(-1.7800)$ & $(-1.9600)$ & $(-1.9400)$ & $(-1.7500)$ & $(0.6000)$ & $(0.9000)$ & $(0.5800)$ \\
\hline \multirow{2}{*}{ GDP } & $-0.0753^{* *}$ & $-0.0731^{* *}$ & $-0.0737^{* *}$ & -0.3395 & -0.2182 & -0.3218 & $-0.1819^{* *}$ & $-0.1584^{* *}$ & $-0.1884^{* * *}$ \\
\hline & $(-2.1500)$ & $(-2.1000)$ & $(-2.1200)$ & $(-0.9400)$ & $(-0.5100)$ & $(-0.8500)$ & $(-2.3900)$ & $(-2.0100)$ & $(-2.2500)$ \\
\hline \multirow{2}{*}{ INF } & 0.0433 & 0.0338 & 0.0378 & $-0.4563^{*}$ & $-0.5811^{*}$ & $-0.5157^{*}$ & 0.0933 & $0.1252^{*}$ & 0.1153 \\
\hline & (1.1800) & $(0.8800)$ & $(1.0100)$ & $(-1.7400)$ & $(-1.7900)$ & $(-1.8500)$ & $(1.4000)$ & $(1.7300)$ & $(1.5200)$ \\
\hline
\end{tabular}




\begin{tabular}{llllllllll} 
& & & & \\
CONS & $0.0226^{* * *}$ & $0.0134^{* *}$ & $0.0242^{* * *}$ & 0.1717 & -0.0089 & 0.1899 & $0.2966^{* * *}$ & $0.3735^{* * *}$ & $0.2898^{* * *}$ \\
$\mathrm{~N}$ & $(3.2300)$ & $(2.0700)$ & $(3.7800)$ & $(1.1900)$ & $(-0.1000)$ & $(1.2700)$ & $(4.4600)$ & $(6.2000)$ & $(4.3500)$ \\
Prob $>\mathrm{F}$ & 351 & 351 & 351 & 351 & 351 & 351 & 351 & 351 & 351 \\
$\mathrm{R}^{2}$ & 0.0000 & 0.0000 & 0.0000 & 0.0000 & 0.0000 & 0.0000 & 0.0000 & 0.0000 & 0.0000 \\
\hline
\end{tabular}

Notes: We estimate all regressions using OLS. ***, **and *indicate significance at the $1 \%, 5 \%$ and $10 \%$ levels, respectively; $\mathrm{t}$ statistics are corrected for heteroskedasticity following White's methodology.

LLP is the ratio of loan loss provisions to total assets. NPL is the ratio of non-performing loans to total loans. CAP is the ratio of equity to total assets. O_C is a dummy variable that equals 1 if the bank is a city commercial bank, and zero otherwise. O_J is a dummy variable that equals 1 if the bank is a joint-stock commercial bank, and zero otherwise. O_F is a dummy variable that equals 1 if the bank is a foreign commercial bank, and zero otherwise. LIST is a dummy variable that equals 1 if the bank is listed in a stock market at 2001-2009, and zero otherwise. SIZE is the log of total assets. L_A is the ratio of loans to total assets. D_A is the ratio of deposits to total assets. LIQ is the ratio of liquid assets to total assets. GDP is the annual percentage growth rate of GDP at market prices based on constant local currency. INF is measured by the consumer price index.

\subsection{Further Analysis ${ }^{5}$}

To further investigate the implication of bank ownership structure and listed status on risk, we analyze the relationship between ownership structure and risk respectively in listed banks, unlisted banks and all banks. The purpose is to explore whether the ownership structure has different effects on risk in the different listed status banks, i.e., whether the listed status moderates the relationship of ownership structure and risk.

Table 5 reports the OLS regression results with bank risk and its components, asset quality (columns 1, 2 and 3), credit risk (columns 4, 5 and 6) and capital adequacy ratio (columns 7, 8 and 9) as dependent variables. For each of these measures we run three OLS regressions. The first columns (1,4 and 7) take the listed banks as a sample. The second columns (2,5 and 8$)$ take the unlisted banks as a sample. The other columns $(3,6$ and 9$)$ contain all the banks. Here, the dummy variable for O_G is excluded so that the estimated coefficients of O_C and O_J measure the effect of each ownership structure on the risk relative to O_Gs. Columns 1, 2 and 3 report the results for regressions of asset quality. O_C and $\mathrm{O}_{-} \mathrm{J}$ have significant negative coefficients in column 1, but are not significant in columns 2 and 3. The LIST dummy variable has a significant negative coefficient in column 3. Columns 4,5 and 6 report the results for regressions of credit risk. O_C and O_J have significant negative coefficients in columns 4, 5 and 6. The LIST dummy variable also has a significant negative coefficient in column 6. Columns 7, 8 and 9 report the results for regressions of capital adequacy ratio. O_C has a significant positive coefficient in column 8 and has no significant coefficient in columns 7 and 9. O_J has a significant positive coefficient in column 8 and has a significant negative coefficient in columns 7 and 9. The LIST dummy variable has a significant positive coefficient in column 9.

Table 5 reports that there are some differences in the direction, size, and significance level of the relationship between the ownership structure and bank risk in the different samples. Do these differences come from the different listed status of samples? In order to explore this problem, we use the analysis of covariance ${ }^{6}$ to analyze the moderating effect of the listed status. Table 6 reports the results of analysis of covariance with bank risk and its components, asset quality (Panel 1), credit risk (Panel 2) and capital adequacy ratio (Panel 3) as dependent variables. We first test the homogeneity of variance before the analysis of covariance, and the result shows that the three panels all pass the test. Then we run the analysis of covariance. The results report the coefficients of interaction in the three panels are all significant (respectively at the 10\%,1\%, and 10\% level). This indicates that the listed status has a significant moderating effect on the relationship between the ownership structure and risk.

\footnotetext{
${ }^{5}$ O_Fs are all unlisted banks, and therefore we cannot consider the variable in the analysis. So in this aspect, "all banks" do not contain the O_Fs.

${ }^{6}$ The explanatory variables and moderated variables are all dummy variables, and the regression does not analyze the moderating effect. So, we choose the analysis of covariance
} 
Table 5: Regressions of bank ownership structure and risk in different samples

\begin{tabular}{|c|c|c|c|c|c|c|c|c|c|}
\hline & \multicolumn{3}{|c|}{ LLP } & \multicolumn{3}{|c|}{ NPL } & \multicolumn{3}{|c|}{ CAP } \\
\hline & 1 & 2 & 3 & 4 & 5 & 6 & 7 & 8 & 9 \\
\hline O_C & $\begin{array}{l}-0.0075^{* * *} \\
(-5.1300)\end{array}$ & $\begin{array}{l}0.0024 \\
(0.6500)\end{array}$ & $\begin{array}{l}-0.0019 \\
(-0.9600)\end{array}$ & $\begin{array}{l}-0.1436^{* * *} \\
(-3.3200)\end{array}$ & $\begin{array}{l}-0.1836^{* * * *} \\
(-3.7500)\end{array}$ & $\begin{array}{l}-0.0892^{* *} \\
(-2.3700)\end{array}$ & $\begin{array}{l}0.0196 \\
(0.7200)\end{array}$ & $\begin{array}{l}0.0213^{\text {*** }} \\
(2.3400)\end{array}$ & $\begin{array}{l}0.0066 \\
(0.9500)\end{array}$ \\
\hline O_J & $\begin{array}{l}-0.0041^{* * *} \\
(-2.5500)\end{array}$ & $\begin{array}{l}0.0019 \\
(0.5700)\end{array}$ & $\begin{array}{l}-0.0004 \\
(-0.2500)\end{array}$ & $\begin{array}{l}-0.0739^{* * *} \\
(-2.8300)\end{array}$ & $\begin{array}{l}-0.2101^{\text {**** }} \\
(-3.9900)\end{array}$ & $\begin{array}{l}-0.0631^{\text {***** }} \\
(-2.9700)\end{array}$ & $\begin{array}{l}-0.0126^{*} \\
(-1.7300)\end{array}$ & $\begin{array}{l}0.0162^{* *} \\
(2.3200)\end{array}$ & $\begin{array}{l}-0.0156^{\text {**** }} \\
(-3.4300)\end{array}$ \\
\hline LIST & & & $\begin{array}{l}-0.0030^{* * *} \\
(-3.4600)\end{array}$ & & & $\begin{array}{l}-0.0326^{*} \\
(-1.7500)\end{array}$ & & & $\begin{array}{l}0.0098^{* * *} \\
(3.4800)\end{array}$ \\
\hline SIZE & $\begin{array}{l}-0.0012^{* *} \\
(-2.6100)\end{array}$ & $\begin{array}{l}-0.0007 \\
(-1.4500)\end{array}$ & $\begin{array}{l}-0.0006^{*} \\
(-1.7400)\end{array}$ & $\begin{array}{l}-0.0221^{* *} \\
(-2.9100)\end{array}$ & $\begin{array}{l}-0.0022 \\
(-0.5100)\end{array}$ & $\begin{array}{l}-0.0011 \\
(-0.2600)\end{array}$ & $\begin{array}{l}0.0036 \\
(1.4000)\end{array}$ & $\begin{array}{l}-0.0004 \\
(-0.2800)\end{array}$ & $\begin{array}{l}-0.0005 \\
(-0.4000)\end{array}$ \\
\hline L_A & $\begin{array}{l}0.0100 \\
(1.4200)\end{array}$ & $\begin{array}{l}-0.0034 \\
(-1.3600)\end{array}$ & $\begin{array}{l}-0.0024 \\
(-1.3500)\end{array}$ & $\begin{array}{l}-0.0261 \\
(-0.4500)\end{array}$ & $\begin{array}{l}-0.0999^{*} \\
(-1.6700)\end{array}$ & $\begin{array}{l}-0.0746 \\
(-1.6100)\end{array}$ & $\begin{array}{l}0.0200 \\
(0.6700)\end{array}$ & $\begin{array}{l}0.0702^{* * * *} \\
(6.3900)\end{array}$ & $\begin{array}{l}0.0571^{* * * *} \\
(5.6900)\end{array}$ \\
\hline D_A & $\begin{array}{l}-0.0104 \\
(-1.0300)\end{array}$ & $\begin{array}{l}0.0156^{* * * *} \\
(2.7700)\end{array}$ & $\begin{array}{l}0.0056 \\
(0.8100)\end{array}$ & $\begin{array}{l}-0.3583^{*} \\
(-1.8000)\end{array}$ & $\begin{array}{l}0.2529^{* *} \\
(2.5000)\end{array}$ & $\begin{array}{l}0.1016 \\
(0.7300)\end{array}$ & $\begin{array}{l}-0.1940^{*} \\
(-1.7700)\end{array}$ & $\begin{array}{l}-0.3418^{* * *} \\
(-2.7400)\end{array}$ & $\begin{array}{l}-0.3128^{* * *} \\
(-3.4300)\end{array}$ \\
\hline LIQ & $\begin{array}{l}0.0016 \\
(0.4000)\end{array}$ & $\begin{array}{l}-0.0184^{*} \\
(-1.6900)\end{array}$ & $\begin{array}{l}-0.0144 \\
(-1.6600)\end{array}$ & $\begin{array}{l}0.0179 \\
(0.2700)\end{array}$ & $\begin{array}{l}-0.1827^{* *} \\
(-2.6100)\end{array}$ & $\begin{array}{l}-0.0956 \\
(-1.6300)\end{array}$ & $\begin{array}{l}0.0236 \\
(1.2300)\end{array}$ & $\begin{array}{l}0.0279 \\
(1.5800)\end{array}$ & $\begin{array}{l}0.0169 \\
(1.1200)\end{array}$ \\
\hline GDP & $\begin{array}{l}-0.0568^{\text {****}} \\
(-2.9600)\end{array}$ & $\begin{array}{l}-0.0772^{*} \\
(-1.6900)\end{array}$ & $\begin{array}{l}-0.0704^{* *} \\
(-1.9400)\end{array}$ & $\begin{array}{l}-0.5504 \\
(-1.2500)\end{array}$ & $\begin{array}{l}-0.1141 \\
(-0.3900)\end{array}$ & $\begin{array}{l}-0.3059 \\
(-0.7500)\end{array}$ & $\begin{array}{l}-0.0031 \\
(-0.0300)\end{array}$ & $\begin{array}{l}-0.2283^{* * * *} \\
(-4.0500)\end{array}$ & $\begin{array}{l}-0.1597^{*} \\
(-1.9600)\end{array}$ \\
\hline INF & $\begin{array}{l}0.0604^{* *} \\
(2.7300)\end{array}$ & $\begin{array}{l}0.0342 \\
(0.7200)\end{array}$ & $\begin{array}{l}0.0372 \\
(0.9800)\end{array}$ & $\begin{array}{l}-0.6556^{* *} \\
(-2.6200)\end{array}$ & $\begin{array}{l}-0.3508 \\
(-1.6200)\end{array}$ & $\begin{array}{l}-0.5256^{*} \\
(-1.8700)\end{array}$ & $\begin{array}{l}0.1590^{*} \\
(2.0600)\end{array}$ & $\begin{array}{l}0.0288 \\
(0.4500)\end{array}$ & $\begin{array}{l}0.0855 \\
(1.3400)\end{array}$ \\
\hline CONS & $\begin{array}{l}0.0350^{* * *} \\
(4.7000)\end{array}$ & $\begin{array}{l}0.0134 \\
(1.0800)\end{array}$ & $\begin{array}{l}0.0241^{* * *} \\
(2.9900)\end{array}$ & $\begin{array}{l}0.8233^{* *} \\
(2.7700)\end{array}$ & $\begin{array}{l}0.1312 \\
(1.4600)\end{array}$ & $\begin{array}{l}0.1597 \\
(0.8300)\end{array}$ & $\begin{array}{l}0.1622 \\
(1.6800)\end{array}$ & $\begin{array}{l}0.3282^{* *} \\
(2.4400)\end{array}$ & $\begin{array}{l}0.3177^{* * * *} \\
(3.3500)\end{array}$ \\
\hline $\mathrm{N}$ & 93 & 243 & 336 & 93 & 243 & 336 & 93 & 243 & 336 \\
\hline Prob $>F$ & 0.0000 & 0.0000 & 0.0000 & 0.0000 & 0.0000 & 0.0000 & 0.0000 & 0.0000 & 0.0000 \\
\hline $\mathrm{R}^{2}$ & 0.2069 & 0.0600 & 0.0965 & 0.3635 & 0.4765 & 0.2624 & 0.6002 & 0.4172 & 0.4294 \\
\hline
\end{tabular}

Notes: We estimate all regressions using OLS. ***, **and *indicate significance at the $1 \%, 5 \%$ and $10 \%$ levels, respectively; $\mathrm{t}$ statistics are corrected for heteroskedasticity following White's methodology.

LLP is the ratio of loan loss provisions to total assets. NPL is the ratio of non-performing loans to total loans. CAP is the ratio of equity to total assets. O_C is a dummy variable that equals 1 if the bank is a city commercial bank, and zero otherwise. O_J is a dummy variable that equals 1 if the bank is a joint-stock commercial bank, and zero otherwise. LIST is a dummy variable that equals 1 if the bank is listed in a stock market at 2001-2009, and zero otherwise. SIZE is the log of total assets. L_A is the ratio of loans to total assets. D_A is the ratio of deposits to total assets. LIQ is the ratio of liquid assets to total assets. GDP is the annual percentage growth rate of GDP at market prices based on constant local currency. INF is measured by the consumer price index.

Table 6: The results of analysis of covariance

\begin{tabular}{|c|c|c|c|c|c|}
\hline \multicolumn{6}{|c|}{ Panel 1: Dependent Variable: LLP; $N=336 ; R^{2}=0.1352$} \\
\hline Source & Partial SS & $\mathrm{DF}$ & MS & $\mathrm{F}$ & Prob $>\mathrm{F}$ \\
\hline OWNER & 0.0000 & 2 & 0.0000 & 0.5900 & 0.5552 \\
\hline LIST & 0.0000 & 1 & 0.0000 & 2.3100 & 0.0734 \\
\hline OWNER*LIST & 0.0002 & 2 & 0.0001 & 2.7900 & 0.0628 \\
\hline \multicolumn{6}{|c|}{ Panel 2: Dependent Variable: NPL; $N=336 ; \mathrm{R}^{2}=0.5512$} \\
\hline Source & Partial SS & DF & MS & $\mathrm{F}$ & Prob $>\mathrm{F}$ \\
\hline OWNER & 0.1311 & 2 & 0.0656 & 62.1100 & 0.0000 \\
\hline LIST & 0.0780 & 1 & 0.0780 & 73.8500 & 0.0000 \\
\hline OWNER*LIST & 0.0598 & 2 & 0.0299 & 28.3100 & 0.0000 \\
\hline \multicolumn{6}{|c|}{ Panel 3: Dependent Variable: CAP; $N=336 ; \mathrm{R}^{2}=0.1883$} \\
\hline Source & Partial SS & $\mathrm{DF}$ & MS & $\mathrm{F}$ & Prob $>\mathrm{F}$ \\
\hline OWNER & 0.0130 & 2 & 0.0065 & 14.4900 & 0.0000 \\
\hline LIST & 0.0055 & 1 & 0.0055 & 12.2700 & 0.0005 \\
\hline OWNER*LIST & 0.0023 & 2 & 0.0011 & 2.5700 & 0.0784 \\
\hline
\end{tabular}

Notes: We explore the moderating effect using analysis of covariance.

OWNER is the ownership structure variable which contains O_G, O_C, and O_J. OWNER*LIST is the interaction variable of ownership structure and listed status. LLP is the ratio of loan loss provisions to total assets. NPL is the ratio of non-performing loans to total loans. CAP is the ratio of equity to total assets. O_G is a dummy variable that equals 1 if the bank is a state-owner commercial bank, and zero otherwise. O_C is a dummy variable that equals 1 if the bank is a city commercial bank, and zero otherwise. O_J is a dummy variable that equals 1 if the bank is a joint-stock commercial bank, and zero otherwise. LIST is a dummy variable that equals 1 if the bank is listed in a stock market at 2001-2009, and zero otherwise. 


\subsection{Robustness Checks}

We test the robustness of our empirical results by different types of analysis. To check the robustness we consider how two alternative measures of bank risk are affected by ownership structure and listed status. The first is asset quality, defined as the loan loss provisions divided by net loans. The second is credit risk, defined as non-performing loans as a percentage of net loans. The last is the capital adequacy ratio, defined as the equity as a percentage of net loans. Table 7 reports the results of alternative measures of bank risk and the results confirm our main finding.

Next, our sample contains not only large state-owned commercial banks, but also small city commercial banks. In order to avoid the non-robustness results due to the different sample sizes, we exclude the samples whose assets are less than 100 million Yuan or more than 500 billion Yuan. Then we run the OLS regressions. The results, not reported, confirm our main finding.

Finally, our final data set consists of China's 94 commercial banks over the period from 2001 to 2009, which can be treated as panel data. The fixed effect model and random effect model are often used to analyze panel data. Therefore, we also run the regression by the random effect model. ${ }^{7}$ The results, not reported, confirm our main finding.

Table 7: Robustness checks

\begin{tabular}{|c|c|c|c|c|c|c|c|c|c|}
\hline & \multicolumn{3}{|c|}{ LLP } & \multicolumn{3}{|c|}{ NPL } & \multicolumn{3}{|c|}{ CAP } \\
\hline & 1 & 2 & 3 & 4 & 5 & 6 & 7 & 8 & 9 \\
\hline \multirow{2}{*}{ O_C } & -0.0011 & & -0.0018 & $-0.0816^{* *}$ & & $-0.0901^{* *}$ & 0.0013 & & 0.0042 \\
\hline & $(-0.5100)$ & & $(-0.9200)$ & $(-2.3200)$ & & $(-2.4400)$ & $(0.2800)$ & & $(0.8600)$ \\
\hline \multirow{2}{*}{ O_J } & -0.0014 & & -0.0005 & $-0.0738^{* * * *}$ & & $-0.0629^{* * * *}$ & $-0.0135^{* * *}$ & & $-0.0185^{* * * *}$ \\
\hline & $(-1.2300)$ & & $(-0.2900)$ & $(-3.1100)$ & & $(-2.5500)$ & $(-3.1200)$ & & $(-3.8900)$ \\
\hline \multirow{2}{*}{ O_F } & $-0.0058^{* * * *}$ & & $-0.0066^{* * * *}$ & $-0.0732^{* *}$ & & $-0.0858^{* *}$ & $0.0336^{* * * *}$ & & $0.0381^{* * * *}$ \\
\hline & $(-2.8500)$ & & $(-3.9600)$ & $(-2.2100)$ & & $(-2.5900)$ & $(5.8500)$ & & $(5.6200)$ \\
\hline \multirow{2}{*}{ LIST } & & $-0.0019^{*}$ & $-0.0028^{* * * * *}$ & & -0.0302 & -0.0319 & & -0.0024 & $0.0114^{* * * *}$ \\
\hline & & $(-1.9100)$ & $(-3.2900)$ & & $(-1.5900)$ & $(-1.5900)$ & & $(-1.0400)$ & $(3.0000)$ \\
\hline \multirow{2}{*}{ SIZE } & $-0.0008^{* *}$ & $-0.0005^{* *}$ & $-0.0005^{*}$ & -0.0033 & $0.0079^{* *}$ & -0.0013 & -0.0002 & -0.0011 & -0.0009 \\
\hline & $(-2.3600)$ & $(-2.1600)$ & $(-1.7500)$ & $(-1.0900)$ & $(2.2400)$ & $(-0.3200)$ & $(-0.1100)$ & $(-1.5100)$ & $(-0.9300)$ \\
\hline \multirow{2}{*}{ L_A } & -0.0009 & $-0.0030^{* * * *}$ & -0.0018 & -0.0556 & $-0.0371^{*}$ & -0.0688 & $0.0639^{* * * *}$ & $0.0613^{* * * *}$ & $0.0678^{* * * *}$ \\
\hline & $(-0.6000)$ & $(-3.1100)$ & $(-1.4400)$ & $(-1.5900)$ & $(-1.6000)$ & $(-1.3500)$ & $(8.7900)$ & $(5.1100)$ & $(9.1400)$ \\
\hline \multirow{2}{*}{ D_A } & $0.0085^{*}$ & $0.0152^{* *}$ & 0.0055 & 0.1048 & 0.0518 & 0.0722 & $-0.2865^{* * *}$ & $-0.3604^{* * * *}$ & $-0.2710^{* * *}$ \\
\hline & $(1.7000)$ & $(2.4100)$ & $(1.1800)$ & $(0.9800)$ & $(0.6200)$ & $(0.7200)$ & $(-4.5400)$ & $(-7.1200)$ & $(-4.1900)$ \\
\hline \multirow{2}{*}{ LIQ } & -0.0134 & $-0.0171^{* *}$ & $-0.0135^{*}$ & $-0.0948^{*}$ & $-0.1187^{*}$ & $-0.1001^{*}$ & 0.0100 & 0.0218 & 0.0102 \\
\hline & $(-1.5900)$ & $(-2.1200)$ & $(-1.7500)$ & $(-1.9200)$ & $(-1.9000)$ & $(-1.7100)$ & $(0.5700)$ & $(0.8400)$ & $(0.5400)$ \\
\hline \multirow{2}{*}{ GDP } & $-0.0749^{* *}$ & $-0.0725^{* * *}$ & $-0.0732^{* * *}$ & -0.3356 & -0.2175 & -0.3198 & $-0.1800^{* * *}$ & $-0.1579^{* * *}$ & $-0.1878^{* * *}$ \\
\hline & $(-2.0900)$ & $(-2.0300)$ & $(-2.1000)$ & $(-0.8500)$ & $(-0.4800)$ & $(-0.7700)$ & $(-2.2600)$ & $(-2.0000)$ & $(-2.1900)$ \\
\hline \multirow{2}{*}{ INF } & 0.0429 & 0.0332 & 0.0369 & $-0.4542^{*}$ & $-0.5788^{*}$ & $-0.5145^{*}$ & 0.0931 & 0.1249 & 0.1152 \\
\hline & $(1.1600)$ & $(0.8100)$ & $(1.0000)$ & $(-1.7200)$ & $(-1.7600)$ & $(-1.7900)$ & (1.3900) & $(1.5100)$ & (1.5000) \\
\hline \multirow{2}{*}{ CONS } & $0.0221^{* * *}$ & $0.0130^{* *}$ & $0.0239^{* * * *}$ & 0.1708 & -0.0084 & 0.1895 & $0.2959^{* * * *}$ & $0.3729^{* * *}$ & $0.2891^{* * * *}$ \\
\hline & $(3.1100)$ & $(2.0000)$ & $(3.6900)$ & $(1.1100)$ & $(-0.0800)$ & $(1.2100)$ & $(4.4200)$ & $(6.1600)$ & $(4.2900)$ \\
\hline $\mathrm{N}$ & 351 & 351 & 351 & 351 & 351 & 351 & 351 & 351 & 351 \\
\hline Prob $>F$ & 0.0000 & 0.0000 & 0.0000 & 0.0000 & 0.0000 & 0.0000 & 0.0000 & 0.0000 & 0.0000 \\
\hline $\mathrm{R} 2$ & 0.1139 & 0.1063 & 0.1276 & 0.2405 & 0.1957 & 0.2701 & 0.5461 & 0.4848 & 0.5565 \\
\hline
\end{tabular}

Notes: We estimate all regressions using OLS. ***, **and *indicate significance at the $1 \%, 5 \%$ and $10 \%$ levels, respectively; $\mathrm{t}$ statistics are corrected for heteroskedasticity following White's methodology.

LLP is the ratio of loan loss provisions to net loans. NPL is the ratio of non-performing loans to net loans. CAP is the ratio of equity to net loans. O_C is a dummy variable that equals 1 if the bank is a city commercial bank, and zero otherwise. O_J is a dummy variable that equals 1 if the bank is a joint-stock commercial bank, and zero otherwise. LIST is a dummy variable that equals 1 if the bank is listed in a stock market at 2001-2009, and zero otherwise. SIZE is the log of total assets. L_A is the ratio of loans to total assets. D_A is the ratio of deposits to total assets. LIQ is the ratio of liquid assets to total assets. GDP is the annual percentage growth rate of GDP at market prices based on constant local currency. INF is measured by the consumer price index.

\footnotetext{
${ }^{7}$ Our variables contain the dummy variables which will lose in the fixed model, so we choose the random effect model. 


\section{CONCLUSIONS}

Ownership reform and listing are important issues in China's commercial banks, and play important roles in the bank development of the Chinese banking industry. This paper investigates the relationship of ownership structure, listed status and risk based on the relevant data of China's 94 commercial banks over the period from 2001 to 2009. The major findings of this study are as follows.

First, foreign-owned commercial banks exhibit a better asset quality, lower credit risk and higher capital adequacy ratio compared to state-owned banks. City commercial banks have lower credit risk than state-owned banks, but have no significant differences in asset quality and capital adequacy ratio. Joint-stock commercial banks have lower credit risk and capital adequacy ratio and no significant differences in asset quality compared to state-owned banks.

Second, bank listing improves asset quality and capital adequacy ratio, and also reduces the credit risk to a certain extent, indicating the regulatory reinforcement effect of bank listing plays a leading role in China's listed banks.

Third, the relationship of ownership structure and risk are different in different listed status samples. The analysis of covariance shows that listed status significantly moderates the relationship between ownership structure and risk.

\section{ACKNOWLEDGEMENTS}

We are grateful for anonymous reviewers. We are also thanks for Baolei Qi providing more helpful for the data collection when he studied at the Hong Kong Polytechnic University in 2010. Funded support from The Humanities and Social Sciences Research Project of Ministry of Education (10YJC790392) and The National Science Foundation of China (71103139). All errors are our own.

\section{AUTHOR INFORMATION}

Maoyong Cheng is a doctoral student in accounting in the School of Management at Xi'an Jiaotong University and a visiting scholar at Colorado State University-Pueblo. His main research interests include corporate governance, bank performance, risk, efficiency, and bank reform. Maoyong Cheng, Affiliation: School of management, Xi'an Jiao tong University, Xi'an, China. Mailing address: No.28, Xianning West Road, Xi'an, Shaanxi, 710049, P.R. China. E-mail: chengmaoyong@126.com

Dr. Hong Zhao is an assistant professor of accounting in the School of Management at Xi'an Jiaotong University and a visiting scholar at Rutgers, the state university of New Jersey. Her main research interests include corporate governance and bank income structure, and she is currently leading the project (No. 71103139) funded by the National Science Foundation of China, and the project funded by The Humanities and Social Sciences Research Project of Ministry of Education (NO. 10YJC790392). Hong Zhao, Ph.D., Affiliation: School of management, Xi'an Jiao tong University, Xi'an, China. Mailing address: 283 chestnut street, Nutley, NJ, 07110, USA. E-mail: zhaored@mail.xjtu.edu.cn (Corresponding author)

Dr. Junrui Zhang is a professor of accounting in the School of Management at Xi'an Jiaotong University. His main research interests include corporate governance, accounting restatements, and earnings management. Author name: Junrui Zhang, Affiliation: School of management, Xi'an Jiao tong University, Xi'an, China. Mailing address: No.28, Xianning West Road, Xi'an, Shaanxi, 710049, P.R. China. E-mail: zhangir@mail.xjtu.edu.cn 


\section{REFERENCES}

1. Anderson, R.C. \& Fraser, D.R. (2000). Corporate Control, Bank Risk Taking, and the Health of the Banking Industry. Journal of Banking and Finance, 24, 1383-1398.

2. Angkinand, A. \& Wihlborg, C. (2010). Deposit Insurance Coverage, Ownership, and Banks' Risk-Taking in Emerging Markets. Journal of International Money and Finance, 29, 252-274.

3. Barry, T.A., Lepetit, L. \& Tarazi, A. (2011). Ownership Structure and Risk in Publicly Held and Privately Owned Banks. Journal of Banking and Finance, 35, 1327-1340.

4. Berger, A.N., Hasan, I. \& Zhou, M.M. (2009). Bank Ownership and Efficiency in China: What Will Happen in the World's Largest Nation? Journal of Banking and Finance, 33, 113-130.

5. Berle, A.A. \& Means G.C. (1932). The Modern Corporation and Private Property, New York: Macmillan.

6. Brandt, L. \& Li H.B. (2003). Bank Discrimination in Transition Economies: Ideology, Information or Incentives? Journal of Comparative Economics, 31, 387-413.

7. Cornett, M.M., Guo, L., Khaksari, S. \& Tehranian, H. (2010). The Impact of State Ownership on Performance Differences in Privately-Owned versus State-Owned Banks: An International Comparison. Journal of Financial Intermediation, 19, 74-94.

8. Cull, R. \& Xu, L.C. (2005). Institutions, Ownership, and Finance: The Determinants of Profit Reinvestment among Chinese Firms. Journal of Financial Economics, 77, 117-146.

9. Fama, E.F. (1980). Agency Problems and the Theory of the Firm. Journal of Political Economy, 88, 288-307.

10. Ferri, G. (2009). Are New Tigers Supplanting Old Mammoths in China's Banking System? Evidence from a Sample of City Commercial Banks. Journal of Banking and Finance, 33, 131-140.

11. Firth, M., Lin, C., Liu, P. \& Wong S.M.L., (2009). Inside the Black Box: Bank Credit Allocation in China's Private Sector. Journal of Banking and Finance, 33, 1144-1155.

12. Forssbæck, J. (2011). Ownership Structure, Market Discipline, and Banks' Risk-Taking Incentives under Deposit Insurance. Journal of Banking and Finance, 35, 2666-2678.

13. Fu, M. \& Heffernan, S. (2009). The Effects of Reform on China's Bank Structure and Performance. Journal of Banking and Finance, 33, 39-52.

14. Garcia-Marco, T. \& Robles-Fernandez, M.D. (2008). Risk-Taking Behavior and Ownership in the Banking Industry: The Spanish Evidence. Journal of Economics and Business, 60, 332-354.

15. Gorton, G. \& Rosen, R. (1995). Corporate Control, Portfolio Choice, and the Decline of Banking. Journal of Finance, 50, 509-527.

16. Haw, I.M., Ho, S., Hu, B. \& Wu, D. (2010). Concentrated Control, Institutions, and Banking Sector: An International Study. Journal of Banking and Finance, 34, 485-497.

17. Iannota, G., Giacomo, N. \& Sironi, A. (2007). Ownership Structure, Risk and Performance in the European Banking Industry. Journal of Banking and Finance, 31, 2127- 2149.

18. Jensen, M.C. \& Meckling, W. (1976). Theory of the Firm: Managerial Behavior, Agency Costs, and Ownership Structure. Journal of Financial Economics, 3, 305-360.

19. Jia, C.H. (2009). The Effect of Ownership on the Prudential Behavior of Banks-The Case of China. Journal of Banking and Finance, 33, 77-87.

20. Kwan, H.K. (2004). Risk and Return of Publicly Held versus Privately Owned Banks. Economic Policy Review, 10, 97-107.

21. Lensink, R., Meeste, A. \& Naaborg, A. (2008). Bank Efficiency and Foreign Ownership: Do Good Institutions Matter? Journal of Banking and Finance, 32, 834-844.

22. Lin, X.C. \& Zhang, Y. (2009). Bank Ownership Reform and Bank Performance in China. Journal of Banking and Finance, 33, 20-29.

23. Micco, A., Panizza, U. \& Yanez, M. (2007). Bank Ownership and Performance. Does Politics Matter? Journal of Banking and Finance, 31, 219-241.

24. Nichols, D., Wahlen J. \& Wieland M. (2009). Publicly-Traded versus Privately-Held: Implications for Conditional Conservatism in Bank Accounting. Review of Accounting Studies, 14, 88-122.

25. Saunders, A., Strock, E. \& Travlos, N. (1990). Ownership Structure, Deregulation and Bank Risk Taking. Journal of Finance, 45, 643-654. 
26. Shehzad, C.T., Haan, J.D. \& Scholtens, B. (2010). The Impact of Bank Ownership Concentration on Impaired Loans and Capital Adequacy. Journal of Banking and Finance, 34, 399-408.

27. Shleifer, A. \& Vishny, R.W. (1997). A Survey of Corporate Governance. Journal of Finance, 52, 737-783.

28. Sullivan, R.J. \& Spong, K.R. (2007). Manager Wealth Concentration, Ownership Structure, and Risk in Commercial Banks. Journal of Financial Intermediation, 16, 229-248. 


\section{$\underline{\text { NOTES }}$}

